\title{
Article
}

\section{Sensory Profile of Greek Islands Thyme Honey}

\author{
Inmaculada Rodríguez ${ }^{1}$, Chrysoula Tananaki ${ }^{2}$, Hortensia Galán-Soldevilla ${ }^{1} \mathbb{1}$, Pilar Ruiz Pérez-Cacho ${ }^{1}$ \\ and Salud Serrano ${ }^{1, *}$ \\ 1 Food Science and Technology Department, University of Córdoba, 14071 Córdoba, Spain; \\ v62rodem@uco.es (I.R.); bt1gasoh@uco.es (H.G.-S.); bt2rupem@uuco.es (P.R.P.-C.) \\ 2 Laboratory of Apiculture-Sericulture, School of Agriculture and Forestry, Aristotle University of Thessaloniki, \\ 54636 Thessaloniki, Greece; tananaki@agro.auth.gr \\ * Correspondence: sserrano@uco.es; Tel.: +34-957212654
}

Citation: Rodríguez, I.; Tananaki, C.; Galán-Soldevilla, H.; Pérez-Cacho, P.R.; Serrano, S. Sensory Profile of Greek Islands Thyme Honey. Appl. Sci. 2021, 11, 9548. https://doi.org/ 10.3390/app11209548

Academic Editor: Jerzy Wilde

Received: 8 September 2021

Accepted: 7 October 2021

Published: 14 October 2021

Publisher's Note: MDPI stays neutral with regard to jurisdictional claims in published maps and institutional affiliations.

Copyright: (c) 2021 by the authors. Licensee MDPI, Basel, Switzerland. This article is an open access article distributed under the terms and conditions of the Creative Commons Attribution (CC BY) license (https:// creativecommons.org/licenses/by/ $4.0 /)$.
Featured Application: The application of this work is to add new data to the characterization of unifloral honeys. Recently, it has been accorded that the best way to authenticate genuine food as honey is by means of rapid non-targeted methods that need to be validated from established patterns describing each of the different unifloral honeys. Sensory profiles responding to specific botanical and geographical origins are an important tool for recognizing the authenticity of a particular honey.

Abstract: The sensory profiles of thyme honey from the Greek islands with different thymus pollen grain contents (A: $>60 \%$, B: 40-60\%, and C: $18-40 \%$ ) were studied. The results of the physico-chemical analyses fulfilled the criteria set by international quality standards and, specifically, Greek legislation (moisture content $<18 \%$, hydroxymethylfurfural $<10 \mathrm{mg} / \mathrm{kg}$, and diastase activity $>20 \mathrm{DN}$ ). The sensory results showed that there were significant differences between groups with different pollen grain contents $(p<0.01)$ for all attributes except for floral aroma, with the Group A samples being the lightest in color $(4.9 \pm 1.8)$ and having the highest floral odor intensity $(5.0 \pm 2.0)$ and salty taste $(3.5 \pm 1.1)$. Additionally, samples with the highest pollen grain content (i.e., Group A) had olfactory notes of wood/wax/resin and a chemical aroma.

Keywords: unifloral thyme honey; physico-chemical parameters; descriptive sensory analysis

\section{Introduction}

Honey is a natural food produced by honeybees from nectar or honeydew varying not only in chemical composition but also in color, taste, and odor [1]. It mainly consists of sugars but also contains many other substances such as proteins, enzymes, minerals, acids, and volatile compounds. Its properties depend on many factors such as the botanical and geographical origin, the intensity of nectar flow, the climatic conditions, the beekeepers' manipulations, the handling and packing procedure, the time of storage, and the conditions of storage [2].

Traditionally, the botanical origin of honey is determined with the use of pollen analysis (i.e., melissopalynology). Although pollen analysis may have several limitations [3,4], the combination of pollen analysis with physico-chemical and organoleptic characteristics can overcome these limitations and provide reliable results [5].

Unfortunately, international legislation that combines these three types of analysis (i.e., pollinic, physico-chemical, and sensory analysis) necessary to authenticate honey does not exist. The Codex Alimentarius Commission [6] and European legislation [7] indicate solely physico-chemical quality criteria. The International Honey Commission (IHC) has made an effort to characterize 15 unifloral honeys that are the most representative in Europe due to their abundance and commercial importance. This work could serve as a starting point for each country to adopt additional parameters to describe domestic honey types [2]. 
Thyme honey is one of the main blossom honeys in Greece and represents $10 \%$ of the total annual Greek honey production. It is mainly produced on the islands and on the mainland where plants of the genus Thymus grow. Thyme blossoms in summer and its nectar flow depends on the weather (i.e., Mediterranean climates). Honeybees collect the nectar and produce aromatic honey that has been famous since ancient times. This type of Greek honey presents higher values of diastase activity and proline than other monofloral honeys [8], and because of its appreciated sensory characteristics, it is sold at higher prices. According to Greek legislation, thyme honey can only be labeled as unifloral if its thyme pollen percentage is equal to or greater than $18 \%$ of the total nectariferous pollen grains, and the total number of pollen grains per $10 \mathrm{~g}$ of honey must also be lower than 90,000.

Several papers have been published on the physico-chemical and microscopic characteristics of thyme honey [9-13]. Especially concerning Greek thyme honey, studies have been conducted on its physico-chemical characteristics, pollen spectrum, mineral content, bioactive compounds, and volatile substances [8,14-17], but no data regarding its sensory characteristics were found. Over the last few years, few studies have been conducted regarding the sensory characteristics of thyme honey $[12,13,18,19]$.

The aim of this study was to determine the sensory profile of thyme honey from the Greek islands with different thymus pollen grain contents.

\section{Materials and Methods}

\subsection{Material}

\subsubsection{Samples Used for Development of the Lexicon}

Fresh thyme honey samples from the Greek islands were collected directly from producers. Instructions were given to beekeepers to collect thyme honey samples from new honeycombs as well as to apply good beekeeping practices during the nectar flow season. After pollen analyses, the thyme honey samples were classified into three classes according to their thymus pollen grain content: A: $>60 \%$, B: $40-60 \%$, and C: $18-40 \%$, and they were stored at $-18^{\circ} \mathrm{C}$ until analysis.

\subsubsection{Samples Used for Sensory Profile}

Nine fresh thyme honey samples, three from each pollen group (A, B, and C), were used to determine the sensory profile.

\subsection{Methods}

\subsubsection{Pollen Analysis}

A qualitative melissopalynological analysis (performed in duplicate) was carried out on all honey samples according to the working methods described by Louveaux et al. (1978) [20] to identify the pollen types and to confirm the dominance of Thymus capitatus L. Counts were expressed as percentages after counting a minimum of 1200 pollen grains on three slides per sample. The pollen slides were examined at 400 and 1000 under a light microscope (Nikon Labophot-2 microscope; Nikon, Tokyo, Japan) to identify the types of pollen.

\subsubsection{Physico-Chemical Parameters}

For the humidity, electrical conductivity, hydroxymethylfurfural (HMF), and diastase activity measurements, the recommended IHC methods were applied [21]. Humidity (moisture) was determined following Chataway (1932) [22] and Wedmore (1955) [23], a method established by the Codex Alimentarius Commission (1969) [24]. We used an Abbetype refractometer, obtaining the corresponding percentage of water from the Chataway table. Electrical conductivity was measured at $20{ }^{\circ} \mathrm{C}$ in a $20 \%(w / v)$ solution of honey (dry matter basis) in deionized water using a Crison model 524 conductimeter (Crison Instruments, Barcelona, Spain), according to Vorwohl (1964) [25]. Hydroxymethylfurfural determination was conducted according to the Winkler method (Winkler, 1955) [26] using a Pharmacia Biotech Ultrospec-3000 spectrophotometer. The results are expressed in 
HMF milligrams per kg of honey. Diastase activity was examined via the procedure of Siegenthaler (1977) [27] and modified by Bogdanov (1984) [28]. Adsorption was followed using a Pharmacia Biotech Ultrospec-3000 spectrophotometer (England). The results were calculated (as Gothe's degrees, ${ }^{\circ} \mathrm{G}$ ) as $\mathrm{ml}$ of $1 \%$ starch hydrolyzed by an enzyme in $1 \mathrm{~g}$ honey for $1 \mathrm{~h}$.

\subsubsection{Sensory Analysis}

Development of the Lexicon

A group of assessors, with previous experience in the sensory analysis of honeys, participated in the flavor lexicon generation (odor/aroma, basic tastes, and trigeminal sensations) using a previously defined vocabulary to describe honeys [29]. This group of assessors was composed of ten highly trained panelists from the Sensory Laboratory at the University of Córdoba (Spain). They were selected and trained following international standards (ISO). The selection of the candidates was based on detection, recognition, and discrimination tests as well as their ability to memorize and communicate sensory impressions. These panelists had prior experience in the sensory evaluation of different products, and they had undergone specific training in honeys. They were exposed in panel booths to a variety of thyme honeys to obtain a comprehensive set of descriptors. The procedure followed to obtain the vocabulary was based on ISO 13299:2016 [30].

\section{Sensory Profile}

The methodology followed was based on ISO 13299:2016 [30]. For each sample, first its odor was analyzed, then its color intensity and its fluidity, next its aroma, basic tastes, and trigeminal sensations, and last its persistence. Thirty grams of each sample was put into a glass vial and covered with a watch glass for sensory analysis. Three samples, labeled with three-digit random numbers, were served, one at a time, over a session, and mineral water was used to cleanse the palate between samples. Testing was carried out in the Sensory Laboratory, which was equipped with a round table for training sessions and individual booths, in accordance with the ISO 8589:2007 [31]. All analyses were conducted in the morning (10 a.m.-12 p.m.).

\section{Statistical Analysis}

Data obtained from physico-chemical parameters and sensory profile were processed using SPSS 17.0 software. A basic descriptive statistical analysis was performed (mean and standard deviation) and one-way ANOVA was applied for each sensory attribute to test mean differences between honeys with different pollen grains, followed by Tukey's test at a $95 \%$ confidence level $(p<0.05)$. In addition, one-way ANOVA was applied for each sensory attribute to test the mean differences between replicates.

\section{Results and Discussion}

\subsection{Development of the Lexicon}

The freshness and authenticity of the tested samples were confirmed by HMF and diastase activity analyses. We rejected samples that had a diastase activity less than $20 \mathrm{DN}$ and those with a 5-(hydroxymethyl)-2-furaldehyde (HMF) of more than $10 \mathrm{mg} / \mathrm{kg}$ to ensure that the samples were fresh, unheated, and authentic [32].

The preliminary flavor vocabulary is presented in Table 1. Odor and aroma attributes were grouped into families and/or subfamilies in a roundtable session under the direction of the panel leader, and a consensus lexicon was developed: floral; fruity-acid (citric and lemon), ripe (raisin), and nutty (almond); vegetal—wood/resin/wax, aromatic herbs (mint); toasty — caramel and smoke; chemical (thymol). The resulting initial working list of terms was composed of nine odor/aroma attributes (i.e., overall intensity, floral, lemon, raisin, almond, wood/resin/wax, caramel, smoke, and chemical), four terms for basic tastes (i.e., sweet, acidic, salty, and bitter), and three for trigeminal sensations (i.e., fresh, astringent, and piquant). In the following panel sessions, the initial working list was 
reduced in accordance with ISO 13299:2016 [30]. Thus, the citric, lemon, raisin, almond, and aromatic herbs odor/aroma attributes, acidic taste, and piquancy were discarded because they did not describe the product. The final list of flavor attributes, definitions, and references for Greek islands thyme honey is presented in Table 2. In addition, color intensity (i.e., appearance), fluidity (i.e., texture), and flavor persistence were also included in the final list of the lexicons, resulting in 14 final attributes (one for appearance, one for texture, six for odor/aroma, three basic tastes, two trigeminal sensations, and flavor persistence).

Table 1. Flavor preliminary descriptors.

\begin{tabular}{|c|c|c|}
\hline Odor/Aroma & Basic Taste & Trigeminal Sensation \\
\hline Overall intensity & \multirow{19}{*}{$\begin{array}{l}\text { Sweet } \\
\text { Salty } \\
\text { Bitter }\end{array}$} & \multirow{19}{*}{$\begin{array}{l}\text { Fresh } \\
\text { Cooling } \\
\text { Astringent } \\
\text { Pungent } \\
\text { Piquant }\end{array}$} \\
\hline Floral & & \\
\hline Fruit & & \\
\hline Acidic fruit & & \\
\hline Citric & & \\
\hline Lemon & & \\
\hline Nutty & & \\
\hline Almond & & \\
\hline Ripe fruit & & \\
\hline Raisin & & \\
\hline Wood & & \\
\hline Wax & & \\
\hline Resin & & \\
\hline Chemical & & \\
\hline Thymol & & \\
\hline Mint & & \\
\hline Aromatic herbs & & \\
\hline Smoke & & \\
\hline Caramel & & \\
\hline
\end{tabular}

Table 2. Sensory attribute definitions and references.

\begin{tabular}{|c|c|c|c|}
\hline Attributes & Definition & Reference Product & Bibliography \\
\hline ODOR/AROMA & $\begin{array}{l}\text { Sensation perceived by the olfactory } \\
\text { organ in sniffing certain volatile } \\
\text { substances (odor) or via the back of the } \\
\text { nose when tasting (aroma). }\end{array}$ & & ISO 5492 \\
\hline Overall intensity & $\begin{array}{l}\text { Strength of the stimuli perceived by the } \\
\text { nose (odor) or by olfactory receptors via } \\
\text { the retronasal method (aroma). }\end{array}$ & & ISO 5492 \\
\hline $\begin{array}{l}\text { Floral family } \\
\text { Floral } \\
\text { Vegetable family }\end{array}$ & Odor associated with different flowers. & Benzyl acetate (0.1 g/L ethanol) & ISO 5496 \\
\hline Wood/resin/wax & $\begin{array}{l}\text { Odor/aroma associated with pine trees, } \\
\text { new furniture, sawdust, wax, and resin. }\end{array}$ & Pine shavings in a $60 \mathrm{~mL}$ flask & Galán et al. 2005 \\
\hline Toasted family & & & \\
\hline Caramel & $\begin{array}{l}\text { Characteristic odor/aroma of } \\
\text { caramelized sugar. }\end{array}$ & Liquid caramel & Galán et al. 2005 \\
\hline $\begin{array}{l}\text { Smoke } \\
\text { Chemical family }\end{array}$ & Characteristic odor/aroma of smoke. & No reference used & \\
\hline Chemical & Odor associated with drugs. & No reference used & \\
\hline BASIC TASTES & $\begin{array}{l}\text { Any one of the distinctive tastes: acidic, } \\
\text { bitter, salty, and sweet. }\end{array}$ & & \\
\hline Sweet & $\begin{array}{l}\text { Primary taste produced by diluted } \\
\text { aqueous solutions of natural or artificial } \\
\text { substances such as sucrose or aspartame. }\end{array}$ & Sucrose (10 g/L water) & ISO 5496 \\
\hline
\end{tabular}


Table 2. Cont.

\begin{tabular}{|c|c|c|c|}
\hline Attributes & Definition & Reference Product & Bibliography \\
\hline Salty & $\begin{array}{l}\text { Primary taste produced by diluted } \\
\text { aqueous solutions of sodium chloride. } \\
\text { Primary taste produced by diluted }\end{array}$ & Salt (1 g/L water) & ISO 5496 \\
\hline Bitter & $\begin{array}{l}\text { aqueous solutions of several products } \\
\text { such as quinine or caffeine. }\end{array}$ & Caffeine (0.03 g/L water) & ISO 5496 \\
\hline $\begin{array}{l}\text { TRIGEMINAL } \\
\text { SENSATIONS }\end{array}$ & $\begin{array}{l}\text { Sensation resulting from irritation caused } \\
\text { by chemical stimuli in the mouth, nose, } \\
\text { or throat. }\end{array}$ & & \\
\hline Fresh & $\begin{array}{c}\text { Sensation of freshness in the buccal } \\
\text { cavity (as produced by eucalyptus oil). } \\
\text { Organoleptic attribute of a pure }\end{array}$ & Minty sweet & \\
\hline Astringency & $\begin{array}{l}\text { substance or mixtures that produce the } \\
\text { astringent sensation. }\end{array}$ & $90 \%$ dark chocolate & \\
\hline
\end{tabular}

The aroma of honey is particularly specific, resulting from the combination of volatile compounds present in low concentrations. Chemical volatile composition has great importance in characterizing honey's botanical source, which directly influences its organoleptic characteristics [33-38]. In this field, Machado et al. (2020) [33] and Karabagias et al. (2016) [39] showed the volatile fingerprint of thyme honey, which exhibits several compounds that vary according to geographical origin, emphasizing the importance of the production area in the final volatile composition.

\subsection{Sensory Profile}

To confirm the freshness and authenticity of the samples, electrical conductivity, moisture, diastase activity, and HMF were determined (Table 3) before the sensory analysis. With respect to the moisture content of honeys, the latter varied between $14.1 \%$ and $18.2 \%$, with a mean value of 15.4. This indicates that all samples were from ripe honey. The electrical conductivity was less than $0.6 \mathrm{mS} / \mathrm{cm}^{3}$ as required by Greek legislation for thyme honey [40]. Regarding HMF and diastase activity, they ranged from $0.9 \mathrm{mg} / \mathrm{kg}$ to $10.0 \mathrm{mg} / \mathrm{kg}$ and from 20.2 to $50.6 \mathrm{DN}$, respectively, coinciding with Thrasyvoulou and Mannikis (1995) [8], who found high diastase values for thyme Greek honey.

Table 3. Physico-chemical characteristics of thyme honey samples $(n=9)$.

\begin{tabular}{ccccc}
\hline & M (\%) & EC $(\mathbf{m S} / \mathbf{c m})$ & HMF (mg/kg) & DA (DN) \\
\hline A1 & 15.3 & 0.600 & 0.9 & 50.6 \\
& 14.6 & 0.319 & 2.5 & 20.2 \\
B & 14.7 & 0.376 & 5.5 & 26.8 \\
& 14.1 & 0.203 & 3.6 & 20.2 \\
C & 15.8 & 0.522 & 10 & 21 \\
& 15.8 & 0.522 & 10 & 21 \\
Minimum & 15.8 & 0.517 & 7 & 20.4 \\
Maximum & 14.4 & 0.468 & 2.8 & 20.2 \\
Mean \pm SD & 18.2 & 0.462 & 8 & 20.2 \\
& 14.1 & 0.203 & 0.9 & 50.6 \\
& 18.2 & 0.600 & 10.0 & $\mathbf{2 6 . 5} \pm 11.5$
\end{tabular}

$\overline{\mathrm{M}}=$ moisture; $\mathrm{EC}$ = electrical conductivity; $\mathrm{HMF}$ = hydroxymethylfurfural; $\mathrm{DA}$ = diastase activity expressed as diastase number.

Table 4 presents the means, standard deviations, and the analyses of variance between honey groups with different pollen grain contents for the sensory attributes studied. 


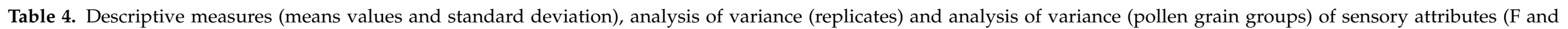
probability values).

\begin{tabular}{|c|c|c|c|c|c|c|c|c|c|c|c|c|c|c|c|}
\hline $\begin{array}{c}\text { Pollen } \\
\text { Grain } \\
\text { Content }\end{array}$ & $\mathbf{S}$ & Color Int. & Fluid & $\begin{array}{l}\text { Overall } \\
\text { Odor Int. }\end{array}$ & $\begin{array}{l}\text { Floral } \\
\text { Odor }\end{array}$ & $\begin{array}{c}\text { Caramel } \\
\text { Odor }\end{array}$ & $\begin{array}{c}\text { Overall } \\
\text { Aroma Int. }\end{array}$ & $\begin{array}{l}\text { Floral } \\
\text { Aroma }\end{array}$ & $\begin{array}{l}\text { Wood } \\
\text { aroma }\end{array}$ & $\begin{array}{l}\text { Caramel } \\
\text { Aroma }\end{array}$ & $\begin{array}{c}\text { Chemical } \\
\text { Aroma }\end{array}$ & $\begin{array}{l}\text { Sweet } \\
\text { Taste }\end{array}$ & $\begin{array}{l}\text { Salty } \\
\text { Taste }\end{array}$ & Fresh & Persistence \\
\hline \multirow{5}{*}{ A } & 1 & $7.1 \pm 0.5^{\mathrm{a}}$ & $4.1 \pm 0.3^{\mathrm{a}}$ & $4.3 \pm 0.3^{\mathrm{a}}$ & $2.3 \pm 0.5^{\mathrm{a}}$ & - & $5.4 \pm 0.3^{\mathrm{a}}$ & $5.3 \pm 0.2^{a}$ & - & - & $5.2 \pm 0.2^{a}$ & $5.1 \pm 0.1^{\mathrm{a}}$ & $5.0 \pm 0.1^{\mathrm{a}}$ & $2.0 \pm 0.4$ & $3.6 \pm 0.3$ \\
\hline & 2 & $2.9 \pm 0.3^{b}$ & $3.9 \pm 0.3^{\mathrm{a}}$ & $3.5 \pm 0.3^{b}$ & $6.3 \pm 0.4^{b}$ & - & $4.3 \pm 0.2^{b}$ & $3.3 \pm 0.2^{b}$ & $3.4 \pm 0.1$ & - & $4.2 \pm 0.2^{b}$ & $5.1 \pm 0.2^{\mathrm{a}}$ & $2.9 \pm 0.3^{\mathrm{b}}$ & $1.4 \pm 0.4$ & $3.8 \pm 0.3$ \\
\hline & 3 & $4.7 \pm 0.5^{\mathrm{c}}$ & $4.9 \pm 0.4^{b}$ & $4.2 \pm 0.3^{\mathrm{a}}$ & $6.5 \pm 0.4^{\mathrm{b}}$ & - & $4.3 \pm 0.2^{b}$ & $3.3 \pm 0.2^{b}$ & $3.9 \pm 0.2$ & - & $4.4 \pm 0.3^{b}$ & $5.8 \pm 0.4^{b}$ & $2.6 \pm 0.3^{b}$ & $1.5 \pm 0.4$ & $3.9 \pm 0.3$ \\
\hline & $\mathbf{M}$ & $4.9 \pm 1.8^{\mathrm{A}}$ & $4.3 \pm 0.6^{B}$ & $4.0 \pm 0.4^{\mathrm{A}}$ & $5.0 \pm 2.0^{B}$ & - & $4.7 \pm 0.6^{\mathrm{A}}$ & $3.9 \pm 1.0$ & $2.4 \pm 1.8$ & - & $4.6 \pm 0.5$ & $5.3 \pm 0.4^{\mathrm{A}}$ & $3.5 \pm 1.1^{\mathrm{A}}$ & $1.7 \pm 0.4$ & $3.8 \pm 0.3^{\mathrm{A}}$ \\
\hline & $\mathrm{F}$ & $\begin{array}{l}109.47 \\
0.001\end{array}$ & $\begin{array}{l}13.65 \\
0.001\end{array}$ & $\begin{array}{l}9.27 \\
0.01\end{array}$ & $\begin{array}{l}155.57 \\
0.001\end{array}$ & - & $\begin{array}{l}38.09 \\
0.001\end{array}$ & $14 \overline{2.46}$ & - & - & 20.51 & 13.72 & 123.17 & ns & ns \\
\hline \multirow{6}{*}{ B } & 1 & $42+05^{a}$ & $49+03$ & $43+04$ & $31+02^{a}$ & - & $41+03$ & $39+02$ & - & - & 0.00 & $49+05^{a}$ & $23+03 a$ & - & $28+04$ a \\
\hline & 2 & $3.8 \pm 0.3^{a}$ & $4.9 \pm 0.3$ & $4.6 \pm 0.3$ & $4.4 \pm 0.5^{\mathrm{a}}$ & - & $3.8 \pm 0.1$ & $3.8 \pm 0.2$ & - & - & - & $4.3 \pm 0.5^{\mathrm{a}}$ & $2.8 \pm 0.2^{b}$ & - & $1.8 \pm 0.5^{b}$ \\
\hline & 3 & $6.2 \pm 0.5^{b}$ & $4.7 \pm 09$ & $3.7 \pm 0.4$ & $3.6 \pm 0.6^{\mathrm{b}}$ & $3.5 \pm 0.5$ & $3.9 \pm 0.5$ & $3.8 \pm 0.6$ & $3.5 \pm 0.7$ & $3.0 \pm 0.8$ & $4.3 \pm 0.2$ & $6.1 \pm 0.4^{b}$ & $1.4 \pm 0.3^{c}$ & - & $3.9 \pm 0.3^{c}$ \\
\hline & $\mathbf{M}$ & $4.7 \pm 1.2^{\mathrm{A}}$ & $4.8 \pm 0.5^{\mathrm{A}}$ & $4.2 \pm 0.5^{\mathrm{A}}$ & $4.1 \pm 0.5^{\mathrm{A}}$ & - & $3.9 \pm 0.3^{\mathrm{AB}}$ & $3.8 \pm 0.4$ & - & 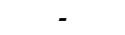 & - & $5.1 \pm 0.9^{\mathrm{A}}$ & $2.2 \pm 0.6^{B}$ & - & $2.8 \pm 0.9^{\text {B }}$ \\
\hline & F & 41.60 & . & & 4.28 & . & & & $-5+2>$ & $-5+2>$ & - & 16.93 & 31.07 & & \\
\hline & $p$ & 0.001 & & ns & 0.05 & - & ns & ns & - & - & - & 0.01 & 0.001 & - & 0.001 \\
\hline \multirow{6}{*}{ C } & 1 & $7.0 \pm 0.5$ & $6.3 \pm 0.5$ & $3.7 \pm 0.5^{\mathrm{a}}$ & $4.2 \pm 0.3^{\mathrm{a}}$ & $3.6 \pm 0.4$ & $3.3 \pm 0.5^{\mathrm{a}}$ & $1.9 \pm 0.2^{\mathrm{a}}$ & - & $3.2 \pm 0.6$ & - & $5.8 \pm 0.4^{\mathrm{a}}$ & $1.4 \pm 0.2^{\mathrm{a}}$ & $1.5 \pm 0.4$ & $4.4 \pm 0.4^{\mathrm{a}}$ \\
\hline & 2 & $6.7 \pm 0.5$ & $5.9 \pm 0.3$ & $6.4 \pm 0.5^{\mathrm{b}}$ & $3.5 \pm 0.3^{b}$ & - & $5.9 \pm 0.6^{b}$ & $5.8 \pm 0.6^{\mathrm{b}}$ & - & - & - & $6.5 \pm 0.4$ & $3.6 \pm 04^{\mathrm{b}}$ & - & $5.4 \underset{\mathrm{ab}}{ \pm} 0.5$ \\
\hline & 3 & $6.5 \pm 04$ & $5.3 \pm 0.8$ & $6.6 \pm 0.3^{\mathrm{b}}$ & $4.1 \pm 0.3^{\mathrm{a}}$ & - & $6.0 \pm 0.3^{\mathrm{b}}$ & $5.9 \pm 0.4^{b}$ & - & - & $5.9 \pm 0.3$ & $6.9 \pm 0.4^{\mathrm{b}}$ & $4.2 \pm 0.3^{b}$ & $3.4 \pm 0.6$ & $6.2 \pm 0.9^{b}$ \\
\hline & M & $6.7 \pm 0.5^{\text {B }}$ & $5.8 \pm 0.7^{\mathrm{B}}$ & $5.6 \pm 1.4^{\mathrm{B}}$ & $3.9 \pm 0.4^{\mathrm{A}}$ & - & $5.1 \pm 1.3^{\mathrm{AC}}$ & $4.5 \pm 1.9$ & - & - & & $6.4 \pm 0.6^{\mathrm{B}}$ & $3.1 \pm 1.3^{\mathrm{A}}$ & $1.6 \pm 1.5$ & $5.3 \pm 1.0^{\mathrm{C}}$ \\
\hline & $\mathrm{F}$ & ns & ns & 75.15 & 8.33 & - & 50.33 & 139.39 & - & - & - & 9.28 & 90.96 & - & 9.43 \\
\hline & $p$ & & & 0.001 & 0.01 & - & 0.001 & 0.001 & - & - & - & 0.01 & 0.001 & - & 0.01 \\
\hline \multicolumn{2}{|c|}{$\mathbf{F}$} & 11.03 & 23.90 & 13.18 & 3.48 & & 6.6 & ns & - & - & - & 16.79 & 6.42 & & 37.56 \\
\hline \multicolumn{2}{|c|}{$p$} & $<0.001$ & $<0.001$ & $<0.001$ & $<0.05$ & & $<0.01$ & ns & - & - & - & $<0.001$ & $<0.01$ & & $<0.001$ \\
\hline
\end{tabular}

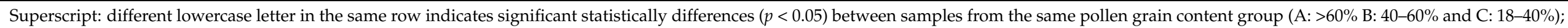

different capital letter in the same row indicates significant statistically differences $(p<0.05)$ between samples from different pollen grain contentngroups. 
The results showed that there was a single qualitative profile with all the honeys being medium in color intensity, thick, with floral olfactory notes, having a sweet and salty taste, and of a low-medium persistence. Additionally, samples from Group A had olfactory notes of wood/wax/resin and a chemical aroma. For common sensory attributes, the results showed significant differences $(p<0.01)$ between groups with different pollen grain contents for all attributes, except for floral aroma, with the Group A samples (thyme pollen content $>60 \%$ ) being the lightest in color and having the highest floral odor intensity and salty taste.

If we compare our findings with other research works, we find that there are very few studies on thyme honey. Greek honeys are described in terms of woody, chemical, and floral-fresh fruit odors, with sweet and acidic tastes, medium persistence, and a medium dark color [4]. Turkish honeys are described in terms of floral, honey, bitter almond, thyme, and wax odors [12], while Spanish honeys are described in terms of aromatic herbs, citric fruit, ripened fruit, caramel, balsamic, and species-specific olfactory notes [13]. The sensory profile determined for Greek islands thyme honey in this work was similar to that defined by Persano Oddo et al. (2004) [4], except for the acidic taste. Over the last few decades, the collected reference works $[13,19,29,41-45]$ evince that since the paper entitled "Main European Unifloral Honeys: Descriptive Sheets" was published [18], there has been an emergence of different working groups presenting honey sensory profiles and, particularly, descriptive techniques for sensory attributes and indications on unifloral honeys from specific geographical areas and their correlation with physico-chemical characteristics. These previous studies have shown that the sensory profile is capable of allowing for differentiation between honeys with different botanical and geographical origins. This may have a certain logic, as consumers' sensory perceptions are the main determinant of their willingness to consume a product. In this sense, the description of honey sensory profiles is a valuable cue for consumers when purchasing a honey type.

It is worth mentioning that the honey sensory profile changes with the pollen grain content, with honeys with a high pollen grain content presenting a floral and chemical olfactory profile ( $>60 \%$, Group A).

Recently, the European Commission [46] concluded that the chemical and biological characteristics of genuine honeys should be generated and stored in a publicly available database. This process would require obtaining samples by authorized personnel from carefully selected honey producers. Moreover, in the private sector, the authenticity of a sample will have to be defined beforehand. In this sense, the sensory profiles of unifloral honeys from different botanical and geographical origins should be studied and introduced in this publicly available database.

\section{Conclusions}

Although there are international regulations (CODEX) and European Union norms that regulate the quality criteria of honeys, they are based solely on physico-chemical parameters (i.e., moisture content, $\mathrm{HMF}$, diastatic activity, electrical conductivity, and sugars) and microscopic analysis. At present, the importance of sensory analysis in establishing authenticity criteria for honeys is more than justified. However, there is limited scientific work that combines the three techniques for the characterization of unifloral honeys. This work contributes to a better characterization of Greek islands thyme honey by determining its sensory profile based on pollen content. A single qualitative profile was obtained, with all of the honeys being medium in color intensity, thick, with floral olfactory notes, having a sweet and salty taste, and of a low-medium persistence. Within this profile, there were significant differences between groups with different pollen grain contents $(p<0.01)$ for all the attributes except for floral aroma, with the Group A samples (thyme pollen content $>60 \%$ ) being the lightest in color and having the highest floral odor intensity and salty taste. 
Author Contributions: Conceptualization, C.T. and S.S.; methodology, H.G.-S. and P.R.P.-C.; formal analysis, C.T., S.S., H.G.-S., P.R.P.-C. and I.R.; investigation, C.T., S.S., I.R., H.G.-S. and P.R.P.-C.; writing-original draft preparation, C.T. and S.S.; writing-review and editing, S.S., I.R., H.G.-S. and P.R.P.-C. All authors have read and agreed to the published version of the manuscript.

Funding: This research received no external funding.

Conflicts of Interest: The authors declare no conflict of interest.

\section{References}

1. Da Silva, P.M.; Gauche, C.; Gonzaga, L.V.; Costa, A.C.O.; Fett, R. Honey: Chemical composition, stability and authenticity. Food Chem. 2016, 196, 309-323. [CrossRef]

2. Thrasyvoulou, A.; Tananaki, C.; Goras, G.; Karazafiris, E.; Dimou, M.; Liolios, V.; Kanelis, D.; Gounari, S. Legislation of honey criteria and standards. J. Apic. Res. 2018, 57, 88-96. [CrossRef]

3. Molan, P.C. The limitations of the methods of identifying the floral source of honeys. Bee World 1998, 79, 59-68. [CrossRef]

4. Persano Oddo, L.; Bogdanov, S. Determination of honey botanical origin: Problems and issues. Apidologie 2004, 35, S2-S3. [CrossRef]

5. Von Der Ohe, W.; Oddo, L.P.; Piana, M.L.; Morlot, M.; Martin, P. Harmonized methods of melissopalynology. Apidologie 2004, 35, S18-S25. [CrossRef]

6. CAC (Codex Alimentarius Commission). Revised Codex Standard for Honey; WHO: Rome, Italy, 2001; pp. $12-1981$.

7. EC (European Commission). The European Union Council Directive 2001/110/EC of 20 December relating to honey. Off. J. Eur. Commun. 2002, 10, 47-52.

8. Thrasyvoulou, A.; Manikis, J. Some physicochemical and microscopic characteristics of Greek unifloral honeys. Apidologie 1995, 26, 441-452. [CrossRef]

9. Tan, S.-T.; Wilkins, A.L.; Holland, P.T.; Mcghie, T.K. Extractives from New Zealand Honeys. 3. Unifloral Thyme and Willow Honey Constituents. J. Agric. Food Chem. 1990, 38, 1833-1838.

10. Terrab, A.; Pontes, A.; Heredia, F.J.; Diez, M.J. A preliminary palynological characterization of Spanish thyme honeys. Bot. J. Linn. Soc. 2004, 146, 323-330. [CrossRef]

11. Terrab, A.; Recamales, A.F.; Hernanz, D.; Heredia, F.J. Characterisation of Spanish thyme honeys by their physicochemical characteristics and mineral contents. Food Chem. 2004, 88, 537-542.

12. Mannas, D.; Altug, T. SPME/GC/MS and sensory flavor profile analysis for estimation of authenticity of thyme honey. Int. J. Food Sci. Technol. 2007, 42, 133-138. [CrossRef]

13. Castro-Vázquez, L.; Díaz-Maroto, M.C.; Gonzàlez-Viñas, M.A.; Pèrez-Coello, M.S. Differentiation of monofloral citrus, rosemary, eucalyptus, lavender, thyme and heather honeys based on volatile composition and sensory descriptive analysis. Food Chem. 2009, 112, 1022-1030. [CrossRef]

14. Tsigouri, A.; Passaloglou-Katrali, M.; Sabakou, O. Palynological characteristics of different unifloral honeys from Greece. Grana 2004, 43, 122-128. [CrossRef]

15. Alissandrakis, E.; Tarantilis, P.A.; Paschalis, C.; Harizanis, P.C.; Polissiou, M. Comparison of the Volatile Composition in Thyme Honeys from Several Origins in Greece. J. Agric. Food Chem. 2007, 55, 8152-8157. [CrossRef] [PubMed]

16. Karabagias, I.K.; Vavoura, M.V.; Badeka, A.; Kontakos, S.; Kontominas, M.G. Differentiation of Greek thyme honeys according to geographical origin based on the combination of phenolic compounds and conventional quality parameters using chemometrics. Food Anal. Methods 2014, 7, 2113-2121. [CrossRef]

17. Karabagias, I.K.; Louppis, P.A.; Karabournioti, S.; Kontakos, S.; Papastepahanou, C.; Kontominas, M.G. Characterization and classification of commercial thyme honeys produced in specific Mediterranean countries according to geographical origin, using physicochemical parameter values and mineral content in combination with chemometrics. Eur. Food Res. Technol. 2017, 243, 889-900. [CrossRef]

18. Persano Oddo, L.; Piro, R. Main European unifloral honeys: Descriptive sheets. Apidologie 2004, 35, S38-S81. [CrossRef]

19. Gonzalez-Viñas, M.A.; Moya, A.; Cabezudo, M.D. Description of the sensory characteristics of Spanish unifloral honeys by free choice profiling. J. Sens. Stud. 2003, 18, 103-113. [CrossRef]

20. Louveaux, J.; Maurizio, A.; Vorwohl, G. Methods of melissopalynology. Bee World 1978, 59, 139-157. [CrossRef]

21. Bogdanov, S. Harmonized Methods of the International Honey Commission. 2009. Available online: http://www.ihc--platform. net/ihcmethods2009.pdf (accessed on 4 September 2021).

22. Chataway, H.D. Determination of moisture in honey. Can. J. Res. 1932, 6, 532-547. [CrossRef]

23. Wedmore, E. The accurate determination of the water content of honeys. Bee World 1955, 36, 197-206. [CrossRef]

24. Codex Alimentarius Commission. Standard for Honey (CAC/RS 12); WHO: Rome, Italy, 1969.

25. Vorwohl, G. Messung der elektrischen Leitfähigkeit des Honigs und der Verwendung der Messwerte zur Sortendiagnose und zum Nachweis von VerfÄlschungen mit Zuckerfütterungshonig. Z. Bienenforsch. 1964, 7, 37-47.

26. Winkler, O. Beitrag zum Nachweis und zur Bestimmung von Oxymethylfurfural in Honig und Kunsthonig. Z. Lebensm. Unters. 1955, 102, 160-167. [CrossRef] 
27. Siegenthaler, U. Eine Einfache und Rasche Methode zur Bestimmung der Alpha-Glucosidase (Saccharase) im Homig. Mitt. Geb. Lebensm. Hyg. 1977, 68, 251-258.

28. Bogdanov, S. Honigdiastase, Gegenüberstellung verschiedener Bestimmungsmethoden. Mitt. Geb. Lebensmittunders Hyg. 1984, 75, 214-220.

29. Galán-Soldevilla, H.; Ruiz-Pérez-Cacho, M.P.; Serrano Jiménez, S.; Jodral Villarejo, M.; Bentabol Manzanares, A. Development of a preliminary sensory lexicon for floral honey. Food Qual. Prefer. 2005, 16, 71-77. [CrossRef]

30. ISO. International Standard 13299. Sensory Analysis. Methodology. General Guidance for Establishing a Sensory Profile. International Organization for Standardization; Ref. No. ISO 13299:2016 (E); ISO: Genéve, Switzerland, 2016.

31. ISO. International Standard 8589. Sensory Analysis. General Guidance for the Design of Test Rooms; International Organization for Standardization; Ref. No. ISO 8589:2007 (E); ISO: Genéve, Switzerland, 2007.

32. Thrasyvoulou, A.; Manikis, J.; Tananaki, C.; Tzelios, D.; Karabournioti, S.; Dimou, M. The characteristics of Greek unifloral honeys. In Proceedings of the 1st Scientific Conference of Apiculture and Sericulture in Greece, Agricultural University of Athens, Athens, Greece, 29 November-1 December 2002; pp. 232-253.

33. Machado, A.M.; Miguel, M.G.; Vilas-Boas, M.; Figueiredo, A.C. Honey Volatiles as a Fingerprint for Botanical Origin-A Review on their Occurrence on Monofloral Honeys. Molecules 2020, 25, 374. [CrossRef]

34. Escriche, I.; Sobrino-Gregorio, L.; Conchado, A.; Juan-Borrás, M. Volatile profile in the accurate labelling of monofloral honey. The case of lavender and thyme honey. Food Chem. 2017, 226, 61-68. [CrossRef]

35. Xagoraris, M.; Revelou, P.K.; Dedegkika, S.; Kanakis, C.D.; Papadopoulos, G.K.; Pappas, C.S.; Tarantilis, P.A. SPME-GC-MS and FTIR-ATR spectroscopic study as a tool for unifloral common Greek honeys' botanical origin identification. Appl. Sci. 2021, 11, 3159. [CrossRef]

36. Madas, N.M.; Marghitas, L.A.; Dezmirean, D.S.; Bonta, V.; Bobis, O.; Fauconnier, M.-L.; Francis, F.; Haubruge, E.; Nguyen, K.B Volatile profile and physico-chemical analysis of acacia honey for geographical origin and nutritional value determination. Foods 2019, 8, 445. [CrossRef]

37. Karabagias, I.K.; Dimitriou, E.; Halatsi, E.; Nikolaou, C. Volatile profile, pigment content, and in vitro radical scavenging activity of flower, thyme, and fir honeys produced in Hellas. J. Food Chem. Nanotechnol. 2017, 3, 98-104. [CrossRef]

38. Karabagias, I.K.; Nikolaou, C.; Karabagias, V.K. Volatile fingerprints of common and rare honeys produced in Greece: In search of PHVMs with implementation of the honey code. Eur. Food Res. Technol. 2019, 245, 23-39. [CrossRef]

39. Karabagias, I.K.; Halatsi, E.Z.; Kontakos, S.; Karabournioti, S.; Kontominas, M.G. Volatile fraction of commercial thyme honeys produced in Mediterranean regions and key volatile compounds for geographical discrimination: A chemometric approach. Int. J. Food Prop. 2016, 20, 2699-2710. [CrossRef]

40. EC (European Commission). Decision of the Greek Higher Chemical Commission Regarding the Characteristics of Monofloral Honey Pine, Fir, Castanea, Erica, Thymus, Citrus, Cotton and Helianthus; No. 127/2004 (FEK 239/B/23-2-2005); EC: Brussels, Belgium, 2004.

41. Marcazzan, G.L.; Mucignal-Caretta, C.; Marchese, C.M.; Piano, M.L. A review of methods for honey sensory analysis. Apic. Res. 2018, 57, 75-87. [CrossRef]

42. Bentabol, A. Aportaciones metodológicas al análisis sensorial descriptivo de las mieles. Descripción de olores y aromas. Alimentaria 2002, 339, 49-52.

43. Ciappini, M.C. Identificación y selección de descriptores para establecer el perfil completo de mieles. Alimentaria 2002, 141-146.

44. Karabagias, I. In Search of Honey Authentication; Cambridge Scholars Publishing: Newcastle upon Tyne, UK, 2021.

45. Rodopoulou, M.A.; Tananaki, C.; Dimou, M.; Liolios, V.; Kanelis, D.; Goras, G.; Thrasyvoulou, A. The determination of the botanical origin in honeys with over-represented pollen: Combination of melissopalynological, sensory and physicochemical analysis. J. Sci. Food Agric. 2018, 98, 2705-2712. [CrossRef]

46. EC (European Commission). Technical Round Table on Honey Authentication; Meeting Report; JRC-Geel: Geel, Belgium, 2018. 